\title{
ANÁLISIS DE LA GESTIÓN ENERGÉTICA EN SISTEMAS DE PRODUCCIÓN GANADEROS
}

\author{
Denoia, J., ${ }^{1,2}$ Bonel, B. ${ }^{1}$, Montico , S. ${ }^{1}$ \& DI Leo, N. ${ }^{1}$
}

\section{RESUMEN}

Se analizó la gestión de la energía en dos sistemas de producción de leche y dos sistemas productores de carne, ubicados en dos regiones agroecológicas diferentes. Se consideraron todos los ingresos de energía al sistema, caracterizados a través de flujos de materia física. La producción obtenida por hectárea se transformó en egreso de energía, empleando los coeficientes de contenido energético de cada producto.

La eficiencia energética y la productividad de la energía fueron los indicadores empleados para analizar los sistemas.

La producción de alimentos fue considerada como un subsistema dentro de cada sistema de producción y cada uno de los cultivos fueron sus componentes. Para cada cultivo se realizó un balance de energía y éstos fueron integrados en otro balance de nivel jerárquico superior, representando al subsistema de alimentación. Finalmente se elaboró un balance para cada sistema de producción, considerando a los alimentos como el ingreso de energía al sistema y los productos como su salida.

La producción de alimentos fue eficiente energéticamente y la productividad de la energía fue alta, en este caso. Los cultivos con altas cantidades de energía indirecta, resultaron los de menor eficiencia y productividad.

La eficiencia y la productividad energéticas de los sistemas de producción de leche y carne fueron bajas respecto a los subsistemas de alimentación que los integraban. Los dos sistemas lecheros resultaron energéticamente más eficientes que los de producción de carne y la productividad de la energía también fue mayor en estos.

Palabras clave: energía, sistemas de producción, balance, ganadería.

\section{SUMMARY}

\section{Analysis of the energy management in livestock production systems.}

The energy management was analyzed in two milk-producing systems and two meat-producing systems, placed in two different agroecological regions. All the energy inputs characterized as the flow of physical matter were considered. The production per hectare was transformed as output of energy using the coefficients of energy content of each product.

1.- Cátedra de Manejo de Tierras. Facultad de Ciencias Agrarias, Universidad Nacional de Rosario. Parque Villarino. C. C. 14. (2125) Zavalla, provincia de Santa Fe.

2.- Cátedra de Estadística. FCA (UNR).

Manuscrito recibido el 28 de enero de 2008 y aceptado para su publicación el 6 de mayo de 2008. 
The energy efficiency and the energy productivity were the parameters used to analyze the systems.

The production of food was considered as a subsystem within each production system and each of the crop were its components. For each crop a energy balance was done and the crops were integrated in another balance hierarchically superior, representing the food subsystem. Finally, a balance was done for each production system, considering the food as the input of energy to the system and the products as output.

The food production was energetically efficient and the energy productivity was high in this case. The crops with high amount of indirect energy resulted in the least efficient and productive.

The energetic efficiency and productivity of the milk and meat-producing systems were low in comparison with the food subsystems that constitute them. The two mil-producing systems were energetically more efficient than the meat-producing systems, and the energy productivity was also higher in the former ones.

Key words: energy, productive systems, balance, livestock. 